DOI https://doi.org/10.18551/rjoas.2018-05.09

\title{
IKHLAS BEHAVIOR AS THE INFLUENCE MODERATOR OF COMPETENCE AND CLIMATE OF SCHOOL ORGANIZATION ON PERFORMANCE OF TEACHERS
}

\author{
Rossanty Niluh Putu Evvy* \\ Faculty of Economic, University of Tadulako, Palu, Indonesia
}

Sudiro Achmad, Armanu, Solimun

Postgraduate Program Faculty of Economic \& Business, University of Brawijaya, Indonesia

*E-mail: nie.rossanty@gmail.com

\begin{abstract}
This study tries to assess the influence of ikhlas behavior as the moderator of competence and the climate of school organization on the performance of teachers in the city of Palu. This explanatory research uses quantitative (positivist) approach. The population is 988 middle-school teachers in Palu, 286 respondents were obtained through probability sampling. The inferential statistical method used in the data analysis is WarpPLS. The results of this study show that competence and the climate of school organization significantly affect the performance of teachers. Meanwhile, behavior of ikhlas does not moderate the effect of competence on teachers' performance. It strengthens the influence of the climate of school organization on the performance of teachers.
\end{abstract}

\section{KEY WORDS}

Ikhlas behavior, competence, climate of school organization, performance, teachers.

Ikhlas is a value rooted from religiosity of Islam. It is a product of faith and contemplation about religious teachings, which leads the behavior of people toward the behavior favored by the teaching they profess. Therefore, it can become a positive value used to improve performance. Religiosity, according to Kaye \& Raghavan (2002), is a spiritual expression from a person regarding belief system of value, applicable law, and ritual. For a teacher, it is reflected in lasting ikhlas, transferring all knowledge and technology with the basis of ikhlas, expecting the contentment of Allah SWT. Ikhlas must accompany all activities. Not limited to religious activity, it applies during working. Satisfying performance is the expectation of all organizations or institutions. Performance is the result of complex process, coming from both the self of every individual (internal factor) and the organizational strategic effort.

As an organization, the performance of school is determined by the performance of its resources. Educational institution must be comprised of resources with high quality and competitiveness. In the context of educational institution, human resources are educational personnel such as the principal, teachers, clerical workers, and helpers (Daulay, 2004). Teacher is the resource that receives more attention in the improvement of educational quality. This certainly relates with the performance of teachers in every school.

The figure of teachers has become a strategic spotlight in education in Indonesia since teachers are connected with all components in educational system. The current phenomenon is that the condition of teachers nowadays has not met the expectation of the government. Many aspects contribute to the quality of education. Danim (2002) stated that one of the characteristics of educational crisis in Indonesia was the low performance of teachers. Some parts of societies still doubt the skill of teachers that is attached to all aspects regarding the performance of teachers. The belief is based on the low average score of UKG (Assessment of Teacher's Competence). The phenomena also appear in the city of Palu, especially among teachers of middle school. Only twelve teachers, out of 630, passed the minimum score of 70. However, score of 10 also appeared (Radar Sulteng, August 13, 2012). The 
result is far from expectation and quite alarming if it is related to the quality and performance of teachers.

Stern (1910) with theory of convergence stated that the working achievement of individual in an organization is determined by factors of individual and environment. Each individual is a combination or convergence of internal factors (inner capability) and external factors. Competence development is a process of merging and improving all skills needed in achieving the domain of life (Sternberg, 2005). This means that competence is a characteristic of someone leading to skill and ability demonstration resulting in effective performance in certain working areas (Sanghi, 2007).

Levenson (2005) asserted that competence could help improve the average quality at work. However, it is not sufficient for identifying and producing outstanding performances for the organization. Executives must have the ability of using their managerial competence and equipping themselves with other managerial competence for the achievement of their organizational goals. The research by Sanda et al. (2011) showed that executives of small companies in Ghana have managerial competence and behavior to improve the performance of their companies. However, they still exhibit competence and attribute of their organizational behavior. This characteristic does not positively affect their performance to the direction that makes their companies more competitive. It also shows that competence is not enough for superior performance. Tutu and Constantin (2012) similarly stated in their research - Understanding Job Performance through Persistence and Job Competency - that a positive correlation existed between performance and competence, but competence is not enough to predict high-level performance. They suggested a more challenging study from social and psychological perspectives, for instance, by observing altruistic in overcoming difficulties at work.

The research of Done (2011) shows that competence and performance have positive and negative effect, that not all dimensions of individual competence positively affect all performance measurement, and that some of them probably have negative effect. This research also raises a prospect that the impact of competence on performance might not always be preferable.

An external factor that comes to the spotlight and can affect the performance of teachers is the climate of school organization. The main factors in organizational climate, according to Bursalioglu and Ceyda (2012) are people and interaction among groups, interaction between school and environment, balance between the objective of the school and the objective of individual, the success level on the achievement of school's objectives. School managers and personal characteristics of other professionals are the main effect on the climate of the organization.

Adeyemi (2008) found that a significant relation existed between the organizational climate of schools and the performance of the teachers. This finding implies that the performance of teachers is the function of the climate of school organization. The positive relation in this study means that the performance of teachers will be high if they work in preferable school climate. Meanwhile, Haron et al. (2010) found that the school climate affects counselor's self-efficacy. It also succeeded in improving understanding about the relation between school climate and self-efficacy of counselors. Effective school climate can improve the performance of counselors in carrying out their duties.

Results of study that supports that organizational climate and performance of teachers correlates each other are the results of Raza (2010). The main objective of this study is to determine the impact of organizational climate on the performance of teachers in public higher educations. The correlation coefficient shows that organizational climate is significantly related to the performance of teachers, with different aspects between the principal and the behavior of teachers. Further, this study also found that teachers in open and autonomous climate performed better than teachers in closed climate did.

The relation between organizational climate and teacher's performance also appears in the finding of Selamat et al. (2013). The findings show that teachers in middle schools cannot perform their duties since the organizational climate of the school is not conducive. This study also finds that organizational climate becomes an important factor affecting the 
performance of teachers. Seen from the dimension of organizational climate, one of the aspects of principal's leadership behavior and teachers' behavior, which are the supporting and the opposing factor, is an important factor in improving the working achievement of teachers.

Duff (2013), in his research trying to assess the climate of school organization, perception of teachers and principal, assessed the extent of the perception gap. This research is a causal comparison using Organizational Climate Description Questionnaire for Elementary Schools (OCDQ-RE) as he instrument of data collection. His findings imply that the perception of teachers on the climate of school organization must also be asked. Knowledge about the climate of school organization is essential in determining and contributing to the success of the school.

Adejumobi and Ojikutu (2013) examined the relation between school climate and the achievement of teachers of middle schools in Lagos State. The multistage cluster sampling that divides Lags State into six educational districts results in samples of 1,804 students, 238 teacher, and 18 principals. The information is extracted from the respondents using Teacher Job Performance Questionnaire (TJPAQ); Organizational Climate Description Questionnaire (OCDQ). A log-linear model is installed to show the interaction among various variables, and it shows that the performance of teachers is affected by variables of infrastructure availability, class size, leadership style, motivational strategy, and teachers' spirit. This shows that relation between climate of school organization and performance of teachers exists.

On the contrary, a research entitled Educators and the quality of their work environment: an analysis of the organizational climate in primary school published by D Vos et al. (2012) shows that teachers in the study do not experience organizational climate of their schools as something positive in creating a conducive environment for teaching and learning activities.

Researches about competence, climate of school organization, and performance of teachers both in national and international scale have been carried out. Factors affecting the performance of teachers have already been examined. Nevertheless, only some of them relate performance of teachers to spiritual and religious values. Therefore, besides convergence of internal and external factors such as competence and climate of school organization, this study discusses more deeply the influence of competence and climate of school organization on performance of teachers with behavior of ikhlas as the moderator.

Only a few researches focus on behavior of ikhlas, but some of them put something similar to the behavior as their focus. For instance, Pendlebury (2008), in Accuracy, Sincerity and Capabilities in the Practice of Teaching, stated that teaching is not a practice. Instead, educative teaching is a definitive practice with the purpose of enabling communal development through skill improvement since it deals with kindness, accuracy, and sincerity. The objective of educative teaching is to enable pupils improving kindness and truth. It sees that teaching practice can be trusted if it is held by teachers who have kindness.

Gürses et al. (2010), in his research entitled An investigation on teachers to whom positive attitudes were developed by students, found that personal feature of teacher is far more effective than their professional knowledge in the process of developing positive attitude. Several personal characteristics such as rhetoric skill, physical appearance, generosity, sensitiveness, and sincerity affect students positively. This can be interpreted as that ikhlas behavior attached to personal characteristic of teacher can highly influence teaching and learning process.

Ozcan and Balyer (2012), in their research entitled Negative factors affecting the process of mentoring at schools, stated that the lack in knowledge-sharing culture, poor communication, competition, and sincerity made mentoring process negative in result. Further results show that junior teachers, 90.1 percent, need more guidance and counseling. It means that teachers need counseling, sincerity, and behavior of ikhlas to make them more comfortable.

The study of Meurs (2011), Political Skill as Moderator of the Trait Sincerity-Task Performance Relationship: A Socioanalytic, Narrow Trait Perspective, uses narrower approach by observing one of the facets, sincerity, where it is one dimension of honesty 
factors, and modesty is measured through personality according to HEXACO factors. The results show that sincerity relates to performance.

The study that focuses specifically on ikhlas is the study by Chizanah (2011), where it compares ikhlas and pro-social through comparative study based on Caps. The results show that fundamental differences exist between ikhlas and pro-social behavior, despite the facts that both involve cognitive and affective elements and that both carry the discourse of idealism (transcendental closeness on ikhlas and moral integrity on pro-social behavior).

The findings of Chizanah (2011) also show that the scale of ikhlas, some parts of it, overlaps the area of other constructs, but not in overall. Thus, it can be said that a unique area can still be explained by ikhlas. The overlapping area in the construct of ikhlas is the aspect of emotional control. The unique areas within the construct of ikhlas are the transcendental motive, conception of God's servant, and superiority feeling.

\section{METHODS OF RESEARCH}

The main objective of this research is to describe the influence of ikhlas behavior as the moderating variable of competence and climate of school organization on the performance of teachers. This study also tries to draw a description about competence of teachers, climate of school organization, ikhlas behavior, and performance of teachers.

The population of this study is teacher of state junior high school (SMP) in the city of Palu. From 24 state junior high schools in Palu, until 2013, the total of teachers, both state's employees (PNS) and non-state's employees, is of 998 people. The sample of this research is 286 people, determined from probability sampling in random manner, where each teacher has the opportunity of becoming the research sample. The instrument of this study is questionnaire used to draw the perception of teachers on competence they have, organizational climate of their school, their ikhlas behavior, and their performance. Particularly for performance variable, questionnaire to be filled by principal as superior is available to assess the performance of teachers.

The methods of analysis are descriptive and inferential analysis. The former gives description on the demography of research's respondents such as age, sex, education, and length of service. The latter assesses the predetermined hypothesis. The statistical inferential method that is relevant with the objective and the framework employed in this study is Partial Least Square (PLS) using WarpPLS 4.0. The stages are assessing the influence of competence on the performance of teachers and assessing the influence of the climate of school organization on the performance of teachers. The next stage is assessing the role of ikhlas behavior in moderating the influence of competence and the climate of school organization on the performance of teachers.

\section{RESULTS AND DISCUSSION}

The result of the descriptive analysis shows that:

For competence variable, the indicator of personal competence has the highest average score, followed by social competence, professional competence, and pedagogic competence.

The variable of climate of school organization is measured from three aspects of principal's behavior (supportive, directive, and restrictive) and three aspects of teacher's behavior (collegial, committed, and disengaged). Based on the result of the descriptive analysis, most of the respondents have good perception about the climate of school organization.

The measurement on the variable of teacher's performance in this research includes planning of teaching activity programs, teaching implementation, and evaluation implementation. Based on the result of the descriptive analysis, the respondents have good perception about the achievement of teachers' performance.

The construct of ikhlas used in this study includes self-concept as servant of God, transcendental motive, superiority feeling, and emotional control. The recapitulation of the 
descriptive analysis of ikhlas behavior variable shows that the respondents have good perception regarding the variable in question.

The hypothetical testing using inferential statistical method gives the following result.

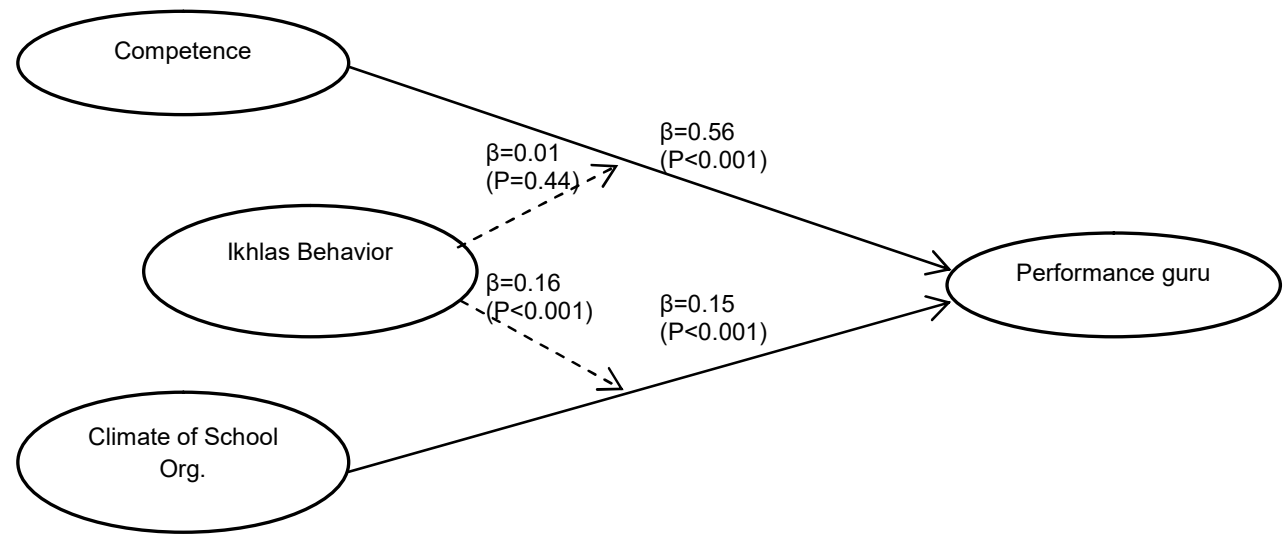

Figure 1 - Path coefficient in the Structural model

Based on the assessment result of the path coefficient of model with moderating variable as shown by Figure 1, it can be seen that (1) competence variable significantly affects the performance of teachers; (2) climate of school organization significantly affects the performance of teachers; (3) variables of competence interaction and ikhlas behavior do not affect the performance of teachers significantly; (4) variables of interaction of school organization climate and ikhlas behavior significantly affect the performance of teachers.

The result of the analysis of this study shows that the influence of competence on teachers' performance is positive and significant with the $P$ value of $<0.001$. The number is lower than 0.05 , as regulated by hypothesis testing. Thus, it can be stated that competence of teachers, which includes pedagogic, personal, social, and professional competence, plays role in determining the performance of teachers. The value of path coefficient and the $P$ value of the model above are presented in Table 1.

Table 1 - Path coefficient and $P$ value

\begin{tabular}{|c|c|c|}
\hline Relation between variables & $\mathrm{B}$ & $\mathrm{P}$ \\
\hline Competence $\rightarrow$ Teacher's performance & 0.564 & $<0.001$ \\
\hline Climate of School Org. $\rightarrow$ Teacher's performance & 0.164 & $<0.001$ \\
\hline Competence* Ikhlas behavior $\rightarrow$ Teacher's performance & 0.008 & 0.438 \\
\hline Climate of School Org. ${ }^{*}$ Ikhlas behavior $\rightarrow$ Teacher's performance & 0.16 & 0.001 \\
\hline
\end{tabular}

Source: Output of WarpPLS, year of 2015 (Enclosure 3).

This result shows that higher competence owned by a teacher will increase his performance. The relation direction between competence and performance of teachers observed at the value of path coefficient can also be seen. The value of path coefficient of competence on teachers' performance is of 0.564 . The value shows that competence positively affects the performance of teachers. Thus, the result of this study proves that better competence will improve performance. In summary, referring to the finding of Spencer and Spencer (1993), competence can be used to predict performance better. The result also support the finding of Abraham et al. (2001), Murray (2003), Quek (2005), Sanda et al. (2011), Levenson (2005) and Done (2011). In a more specific manner, this study support the result of the previous study regarding the performance of teachers, such as Bisschoff \& Grobler (1998), Chung and Wu (2011), Ilanlou and Zand (2011), Kamis (2013), and Richards (2010).

Mastery of competence for a teacher has an important value for the teacher himself, for the school, and for students. Referring, once again, to the finding of Spencer \& Spencer (1993), competence is causally related with performance. Thus, pedagogic, personal, social, 
and professional competences are expected to predict the behavior of teachers, so it eventually can predict the performance of the teacher.

The finding in the variable of school organization climate shows that its $P$ value is of $<0.001$, which means the climate of organizational school affects teachers" performance. Besides influence, the direction can also be seen form the path coefficient value, which is of 0.164 . The value shows that the climate of school organization positively affects the performance of teachers. It means that performance of teachers will improve if the school has good organizational climate.

Climate is a general concept reflecting the quality of the organization's life. The quality is observed from many perspectives. One of the concepts and climate measurement is observed from actors of superiors and subordinates. The result of this study shows that the climate of school organization significantly affects teachers' performance. It means that conducive organizational climate is shaped from three aspects of principal's behavior (supportive, directive, and restrictive) and three aspects of teachers' behavior (collegial, committed, and disengaged). Based on the description on the variable of school organization's climate, most of the principals are high in support, but they are low in giving direction and making restriction.

Besides the behavior of principal, the climate of school organization is also shaped by the relation among teachers, a series of working environment's characteristics measured directly and indirectly by teachers who are assumed the main power in influencing the behavior of teachers (Gibson et al., 1995).

One of the behaviors of teachers that shape the climate of school organization is collegial. A good cooperation will create a friendly, familiar, respecting, and supportive community, which ensure the teaching and education in the school, especially in creating warm and supportive climate of school organization.

The description of school organization climate dealing with the behavior of a teacher to his colleagues shows that commitment, which is measured from the consequences of teachers such as helping their students, willing to stay after teaching hours to give extra lesson to students in need, voluntarily supports students' activity after their teaching hours, and listening to students with personal problems, is quite good. Teacher with high commitment will give effective contribution to students (Vikramsinh, 2013). The findings of Smith (2009) show that teachers tend to be committed to their school if they feel support from other teachers.

This study also shows that disengagement rarely happens, which means that conflict does not occur frequently. Reprehensible conducts such as putting pressure to other teacher groups with different opinion, talking inappropriately during school meeting, ignoring opinions of other teachers, or gossiping do not present.

This result is similar to the result of Makewa et al. (2011). Climate of school has a significant influence on academic performance of students in middle schools located in the regency of Nandi-tengah. The study recommends the schools improve their ecology, environment, social climate, and school culture, so they have positive climate, which supports better academic achievement for the students. Organizational climate is significantly related to the performance of teachers, with different behavioral aspects of principals and teachers (Raza, 2010). The result of this study is consistent with the finding of Kelton (2010), which mentions that it is essential to establish supportive behavior of principals and committed and collegial behavior of teachers.

This research and several previous researches have shown that organizational climate is an important factor that can influence the performance of teachers. The finding is similar to the findings of Selamat et al. (2013), Duff (2013), Adejumobi and Ojikutu (2013), and Aladenusi and Ayodele (2014). This study is slightly different from the research of D Vos et al. (2012), which shows that the teachers mentioned in the study do not experience climate that is positive enough for environment conducive for teaching and learning.

Thus, the role of principals and the behavior of teachers highly determine the organizational climate of the school. Principals as leaders of schools are responsible for the smooth flow of the teaching and learning process in the school they lead. Adejumobi and 
Ojikutu (2013), in their research, show that relation between leadership style and working achievement of teachers at schools is significant. Perception of teachers on the leadership of their principal is highly influential to the implementation of their professional tasks because principal is the leader of the school and their direct superior. A good perception of teachers toward the leadership of their principal will stimulate them to work better.

The assessment on the effect of competence on the performance of teacher moderated by ikhlas behavior is an interaction value between competence and ikhlas behavior against the performance of teachers. The measurement result presented in Table 1 shows path coefficient of 0.008 with the $P$ value of 0.483 . The $P$ value is greater than 0.05 , which means there is no interaction between competence and ikhlas behavior in affecting the performance of teachers. In other words, ikhlas behavior is not the moderating variable of competence and performance of teachers. It can be interpreted that high competence together with ikhlas behavior has not been able to show a positive relation with performance.

Different results are shown in the assessment result on the influence of interaction between climate of school organization with ikhlas behavior and performance of teachers. The results shows path coefficient of 0.16 with the $P$ value of 0.001 , which is lower than 0.05 . It means that interaction between climate of school organization and ikhlas behavior in influencing performance of teacher exists. This shows that ikhlas behavior moderates climate of school organization and performance of teachers. The positive path coefficient shows that ikhlas behavior strengthens the influence of school organization's climate in influencing performance of teachers to positive direction. Therefore, better climate of school organization, together with high ikhlas behavior, will improve performance of teachers.

The results of the study on junior high school teachers of the city of Palu show that ikhlas behavior is highly influential in improving the performance of the teachers. In accordance with the result of Gürses et al. (2010), personal feature of teachers is more effective than their professional knowledge in their work accomplishment. Similar results appear from the interview on several teachers and all principals of the schools that become the object of the research that teachers of junior high school must put emphasizes on ikhlas behavior since it brings up the nature of teachers, which are parents for students.

\section{CONCLUSION}

Based on the findings and the discussions of this study, conclusions that can be drawn are:

Good competence can improve the performance of teachers. Competences of teachers, which are pedagogic, personal, social, and professional competence, have an important role in the achievement of teachers' performance. The result of this study is that pedagogic competence is perceived as the most important competence in improving the performance of teachers. It means that pedagogic competence, which is measured through arrangement of lesson plan, teaching implementation, and evaluation, gives a real contribution to the performance of teachers.

Climate of school organization positively influences the performance of teachers. The results of the study show that, from external dimension - climate of school organization supportive behavior of principals is perceived to be important in improving the performance of teachers. Further, the behavior of open and supportive that promotes interactions among teachers professionally also plays a role in creating good climate of school organization.

Behavior of ikhlas is a variable that does not moderate the influence of the independent variable (competence) on the dependent variable (teachers' performance). Therefore, competence is a variable that is not influenced by the interaction of ikhlas behavior variable. Nevertheless, ikhlas behavior moderates the relation between climate of school organization and performance of teachers. Good climate of school organization will affect performance of teachers, and the influence will be stronger if interaction with ikhlas behavior variable is present. Superiority feeling is the most important factor that reflects ikhlas behavior. It harms the behavior of ikhlas, which means that lower superiority feeling will improve the achievement of ikhlas behavior of teachers. 


\section{REFERENCES}

1. Abraham, Steven E; Lanny A Karns; Kenneth Shaw; Manuel A Mena. 2001. Managerial Competencies And The Managerial Performance Appraisal Process. The Journal of Management Development, Vol. 20 No. 10, pp 842-852.

2. Adejumobi, Faislat Titilayo and Rasheed Kola Ojikutu. 2013. School climate and teacher job performance in Lagos state Nigeria. Discourse Journal of Educational Research. www.resjournals.org/IJER Vol.1(2); pp. 26-36.

3. Adeyemi, T.O. 2008. Organisational Climate and Teachers' Job Performance in Primary Schools in Ondo State, Nigeria: An Analytical Survey. Asian Journal of Information Technology 7 (4): 138-145.

4. Aladenusi, O. and Ayodele, K. 2014. Counterproductive Behaviour and Job Performance among Secondary School Teachers: School Climate as a Mediator. Journal of Education and Practice ISSN 2222-1735 (Paper) ISSN 2222-288X (Online)Vol.5, No.8, 2014.

5. Bisschoff, Tom \& Bennie Grobler. 1998. The management of teacher competence, Journal of In-Service Education, 24:2, 191-211.

6. Ceyda, Gunes, Peker Sevinc. 2012. Determination of High Schools Organizational Climate. Procedia - Social and Behavioral Sciences 46, 2947 - 2950.

7. Chizanah, Lu'luatul. 2011. Ikhlas = Prososial ? (Studi Komparasi Berdasar Caps) PSIKOISLAMKA, Jurnal Psikologi Islam (JPI) Vol. 8 No. 2 Tahun 2011.

8. Chizanah, Lu'luatul dan M. Noor Rochman Hadjam. 2011. Validitas Konstruk Ikhlas: Analisis Faktor Eksploratori Terhadap Instrumen Skala Ikhlas. Jurnal Psikologi Volume 38, No.2: 199-214.

9. Chizanah, Lu'luatul dan M. Noor Rochman Hadjam. 2013. Penyusunan Instrumen Pengukuran Ikhlas. Jurnal Psikologika Volume 18 Nomor 1.

10. Chung, Ruey-Gwo and Chien-Yao Wu. 2011. The identification of personnel director's competency profile through the use of the job competence assessment method, African Journal of Business Management Vol. 5 (2), pp. 405-415, 18.

11. Danim,Sudarwan. 2010. Kepemimpinan Pendidikan Kepemimpinan Jenius (IQ + EQ), Etika, Perilaku Motivasional, dan Mitos. Bandung: Alfabeta.

12. Danim, Sudarwan. 2002. Inovasi Pendidikan Dalam Upaya Peningkatan Professional Tenaga Pendidikan. Bandung: Pustaka Setia.

13. Daulay, Putra Haidar, 2004, Pendidikan Islam dalam Sistem Pendidikan Nasional di Indonesia, Jakarta, Prenada Mulia.

14. D Vos, Philip C van der Westhuizen, P J Mentz, S M Ellis. 2012. Educators And The Quality Of Their Work Environment: An Analysis Of The Organizational Climate In Primary Schools. South African Journal of Education, Vol. 32:56-68

15. Duff, Brandy Kinlaw . 2013. Differences In Assessments Of Organizational School Climate Between Teachers And Administrators. A Dissertation Presented in Partial Fulfillment Of the Requirements for the Degree Doctor of Education. Liberty University, Lynchburg, VA.

16. Gibson, Ivan Cevich, Donnelly. 1995. Organisasi, Perilaku, Struktur, Proses, Terjemahan, Penerbit Bina Rupa Aksara, Jakarta.

17. Gürses, Ahmet, Tuba Çamuroglu, Metin Açikyldiz dan Çetin Dogar .2010. An investigation on teachers to whom positive attitudes were developed by students. Procedia Social and Behavioral Sciences.

18. Haron, Suzana, Wan Marzuki Wan Jaafar, Maznah Baba. 2010. The influence of school climate towards counselor's self-efficacy. Procedia Social and Behavioral Sciences 5, 445-448.

19. Ilanlou, Maryam, Maryam Zand. 2011. Professional Competencies of Teachers and the Qualitative Evaluation. Procedia - Social and Behavioral Sciences 29, 1143 - 1150.

20. Kamis, Ruslan Ade. 2013. The Influence of Organizational Commitment and Individual Competence on Teacher Performance: In the Learning Organization Perspective. International Journal of Business and Behavioral Sciences. Vol.3 No.8. 
21. Kaye, Judy dan Senthil Kumar Raghavan. 2002. Spirituality in Disability and Illness. Journal of Religion and Health September, Volume 41, Issue 3, pp 231-242.

22. Kelton, Kathryn E. 2010. A Study Of The Comparison Between Teacher Perceptions Of School Climate And The Existence Of Professional Learning Community Dimensions. A dissertation submitted in partial fulfillment of the requirements for the degree of Doctor of Education University of Central Florida Orlando, Florida.

23. Levenson, Alec. 2005. Do competencies drive organizational performance? Can they? Evidence and implications for professional and HR competencies. Center of Effective Organizations - Marshall School of University of Southern California- Los Angeles.

24. Makewa, L. Ndiku, E. Role, Jesse Role, E. Yegoh. 2011. School Climate and Academic Performance in High and Low Achieving Schools: Nandi Central District, Kenya. International Journal of Scientific Research in Education, Vol. 4(2), 93-104.

25. Meurs, James A., Pamela L. Perrewé \& Gerald R. Ferris (2011): Political Skill as Moderator of the Trait Sincerity-Task Performance Relationship: A Socioanalytic, Narrow Trait Perspective, Human Performance, 24:2, 119-134

26. Muray, Peter. 2003. Organizational Learning, Competencies and Firm Performance: Emperical Observations, The Learning Organization, Vol.10, pp. 305-313.

27. Ozcan, Kenan dan Aydin Balyer .2012. Negative factors affecting the process of mentoring at school, Procedia - Social and Behavioral Sciences 46 (2012) 5414 - 5419.

28. Pendlebury, Shirley .2008. Accuracy, Sincerity and Capabilities in the Practice of Teaching. Springer Science+Business Media B.V.

29. Quek, Ai-Hwa. 2005. Learning for The Workplace: Acase Study in Graduate Employees' Generic Competencies. Journal of Workplace Learning, Vol. 17 No. 4, pp 231-242.

30. Raza, Syed Ahmad. 2010. Relationship between organizational climate and performance of teachers in public and private colleges of Punjab. (Doctoral dissertation, University Institute of Education and Research, Pir Mehr Ali Shah, Arid Agriculture University Rawalpindi and University Rawalpindi).

31. Raza, Syed Ahmad 2010. Impact of Organizational Climate On Performance Of College Teachers In Punjab. Journal of College Teaching \& Learning, 7(10), 47-52.

32. Richards, Jack C., 2010. Competence and Performance in Language Teaching. Regional Language Centre Journal 41(2) 101-122.

33. Sanda.A, Joceln Sackey, Ylva Fältholm. 2011. Managerial Competence and NonPerformance of Small Firms in a Developing Economy. International Journal of Contemporary Business Studies Vol: 2, No: 3. ISSN 2156-7506.

34. Sanghi, Seema. 2007. The Handbook of Competency Mapping, Understanding, Designing and Implementing Competency Models in Organizations. Chaman Enterprises.

35. Selamat, Nurharani, Nur Zahira Samsu dan Nur Shaminah Mustafa Kamalu. 2013. The Impact of Organizational Climate on Teachers' Job Performance. Educational Research eJournal ISSN 2254-0385, Faculty of Education. University of Alicante.

36. Smith, Larry Don. 2009. School Climate And Teacher Commitment. Dissertation For The Degree Of Doctor Of Education In The Department Of Educational Leadership, Policy, And Technology Studies In The Graduate School Of The University Of Alabama.

37. Spencer, Lyle \& Singe M. Spencer. 1993. Competence At Work Models For Superior Performance. Canada: John Wiley \& Son.

38. Stern, Willian. 1910. Abstracts of Lectures on the Psychology of Testimony and on the Study of Individuality. The American Journal of Psychology, Vol. 21, No. 2 (Apr., 1910), pp. 270-282. http://www.jstor.org/stable/1413003.

39. Sternberg, R.J. 2005. The Theory of Successfull Intelligence. Interamerican Journal of Psychology [on-line] Diakses pada 21 Maret 2011 dari http://www.psicorip.org/Resumos/PerP/RIP/RIP036a0/RIP03921.pdf.

40. Tutu, Andreea, 2012. Understanding job performance through persistence and job competency. Procedia - Social and Behavioral Sciences 33, 612-616.

41. Vikramsinh, Rathod Mahipalsinh. 2013. Teacher's Work Commitment for School and Students. An International Multidiscplinary Peer Reviewed \& Journal. Volume 2, IssueIV, November-Desember. 